$\begin{array}{ll} & \text { Etnográfica } \\ \text { etnográfica } & \text { Revista do Centro em Rede de Investigação em }\end{array}$

Antropologia

vol. $17(3) \mid 2013$

Vol. $17(3)$

\title{
Landscapes, soundscapes, mindscapes: introduction
}

Paisagem, paisagem sonora e paisagem mental: introdução

\section{Eckehard Pistrick and Cyril Isnart}

\section{(2) OpenEdition}

\section{Journals}

Electronic version

URL: https://journals.openedition.org/etnografica/3213

DOI: 10.4000/etnografica.3213

ISSN: 2182-2891

\section{Publisher}

Centro em Rede de Investigação em Antropologia

\section{Printed version}

Date of publication: 30 October 2013

Number of pages: $503-513$

ISSN: 0873-6561

\section{Electronic reference}

Eckehard Pistrick and Cyril Isnart, "Landscapes, soundscapes, mindscapes: introduction", Etnográfica [Online], vol. 17 (3) | 2013, Online since 31 October 2013, connection on 09 February 2022. URL: http:// journals.openedition.org/etnografica/3213 ; DOI: https://doi.org/10.4000/etnografica.3213

\section{(c) (i) (8)}

Etnográfica is licensed under a Creative Commons Attribution-NonCommercial 4.0 International License. 


\section{Landscapes, soundscapes, mindscapes: introduction}

\section{Eckehard Pistrick and Cyril Isnart}

This article aims at providing a state of the art of current interdisciplinary and comparative research approaches on the intrinsic links between sound and place. It explores the role of sound in appropriating and humanizing space, turning it into a place, a site of human intervention and sociocultural practice. The authors direct as well to the various refigurations of the sound and place correlation in an era of increased de-territorialization, transregionalization, and hybridization of cultural practice.

KEYWORDS: sound, space, place, landscape, ethnomusicology, anthropology of the senses.

Paisagem, paisagem sonora e paisagem mental: introdução - Pretende-se neste artigo fazer um balanço da investigação comparativa e interdisciplinar atual acerca das ligações intrínsecas entre som e lugar. É analisado o papel do som na apropriação e humanização do espaço, que assim se torna lugar, local de intervenção humana e prática sociocultural. São também tratadas as várias reconfigurações da correlação entre som e lugar, numa época de crescente desterritorialização, transregionalização e hibridismo na prática cultural.

PALAVRAS-CHAVE: som, espaço, lugar, paisagem, etnomusicologia, antropologia dos sentidos.

PISTRICK, Eckehard (eckehard.pistrick@musikwiss.uni-halle.de) - Martin-Luther-Universität Halle-Wittenberg, Germany.

ISNART, Cyril (isnart@uevora.pt) - Cidehus, Universidade de Évora, Portugal. 
LANDSCAPES AND SOUNDSCAPES ${ }^{1}$ SURROUND US IN OUR EVERYDAY lives even if we do not always recognize their existence. They are two phenomena which appeal to our sensory capacities and which share comparable features: they both possess a recognizable form, they are both culturally shaped and they are symbolic points of reference for humans. They are of immanent importance to us as we recognize our being in the world through hearing, feeling, smelling and seeing our environment. In this sense our environment is not divided along the lines of sensory pathways by which we enter it (see Ingold 2007). Sound (as well as vision and smell) and space mutually reinforce one another in our perception, "the qualities of a space affect how we perceive a sound and those of a sound affect how we perceive a space" (Ripley 2007a: 2) or as Steven Feld puts it, "place is sensed, senses are placed; as places make sense, senses make place" (2005: 179).

Considering space and sound as one entity responds to the phenomenological turn in anthropology heralded by authors such as Feld (1982), Stoller (1989), and Howes (1991), and most recently prominently represented in the works of Tim Ingold (201 1; Jankowski and Ingold 2012). This point of view takes into account that sounds are an essential part of the affective and aesthetic properties of a place and that they influence profoundly how we experience places sensually. Moreover, sound can convene a sense of place as "belonging to us", combined with a heightened sense of community. This approach is also backed by recent calls for a geomusicology (Carney 1998; Cler 1999) or a "sonic geography" (Matless 2005). In this sense, it seemed logical to consider the topic as a field in which social anthropology, geography and ethnomusicology converge.

This dossier aims at analyzing the intrinsic links between sound and place in a broad interdisciplinary and comparative perspective. It intends to bring into the foreground the often hidden interconnection between two phenomenological entities which surround us. It shall explore the different ways in which place is sensually and bodily experienced in different cultural contexts. It explores the role of sound in appropriating and humanizing space, turning it into a place, a site of human intervention and sociocultural practice. Space is understood by us not in its abstract dimension but as the "simultaneous coexistence of social interrelations at all geographical scales" (Massey 1992: 12). With place we refer, in the non-essentialist reading of Massey, to an interconnected place which "is formed out of the particular set of social relations which interact at a particular location" (1992: 12).

I Although using it, we recognize the growing concern with the term soundscape. The critics point particularly to the regular confusion of sound with hearing and the idea that sound is exclusively considered an object of perception. According to Ingold (2007), sound should be considered neither as mental nor as material but as a medium of perception, as a phenomenon of experience in which we are immersed. 
The articles presented here build on previous existing works on the sensory ethnography of place, ${ }^{2}$ on the role of the auditory sense (Erlmann 2004; Bandt, Duffy and MacKinnon 2007) and on the tradition of acoustic ecology and soundscapes studies introduced by the Canadian composer Murray Schafer, anthropologically applied through the works of Steven Feld (1982, 2005). It also takes into consideration a wide range of studies which are seeking to (re)connect musical practice to place and locality (e.g. Leyshon, Matless and Revill 1998, and Labelle 2010). This emphasis on the local meaning of sounds, which for Biddle and Knights (2007) coincides with an idealization of place, can be seen as a reaction in times of increasingly de-territorialized musical objects.

\section{SOUNDS AND THE MAKING OF PLACE}

Space is a historical palimpsest with different layers of time, charged with multiple meanings, symbols and myths. Space becomes a place through human experience but also through our memory and imagination. "Place becomes a center of meaning constructed by experience" (Tuan 1975: 152), a part of a specific cultural design. This act of place-making changes us as well: we make places, they make us in turn.

Place is considered here not as a static entity but as a cultural process, as a continuously defined and redefined point of reference which may be both real and imaginary. It emerges as experience, as a category only through a wide range of human activities such as making routes, forming aesthetics and narrating (Árnason et al. 2012: 1). Place is socially constructed (Halbwachs 1992 [1941]; de Certeau 1984) and perceived by its inhabitants. Its meanings between past, present and future are continuously (re)imagined, questioned, and reformulated (see Jankowski and Ingold 2012). Places are unbounded "meeting places" whose significance is constructed out of interrelations with elsewhere (Massey 1992).

The acoustic dimensions of place have been acknowledged by geographers relatively early (Seamon and Mugerauer 1985); nevertheless this sonic dimension of place was never explored in depth. This has partially changed with the emotional turn in geographical studies. With recognising the fact that emotions are both constitutive for spatial construction and for the attachment of meanings to place (e.g. Davidson and Milligan 2004; Davidson, Bondi and Smith 2005), also the potential of narratives, histories and sounds in memorizing and emotionalizing place was reconsidered. Nevertheless, the role of sounds has remained still at the margins of this discussion. This is surprising as 
sounds play a crucial role in charging place with meaning, in stimulating emotional attachment: they are constitutive for the act of place-making. Sounds mobilize feelings of belonging and nostalgia, they may transmit a (virtual) idea of home, and they may fill a place with ideas about the past, the present and the future. They are even capable of creating evocative mindscapes with reference to physical realities. ${ }^{3}$

The general framework in which we discuss sonic practices as place-making here is to consider sounds both as being placed and as existing beyond place: local sounds with their potential to demarcate and comment on places and global sounds which exist in multiple places at the same time or beyond the limits of a physical place. In the postmodern extension of this idea we might think of sounds as coordinates which allow us to orient in a connected global world, teaching us "how to belong, to find place, as well as how not to belong, to drift" (Labelle 2010: xvii).

To know about a place means to know about the particular sonic properties of this place. Spatial experience therefore incorporates a certain auditory knowledge. This pronounced interconnection between sound and place implies that sounds take actively part in the social construction of our spatial and temporal environment. They are part both of the "spatial practices" and "spatial representations" as evoked by Lefebvre (1974). Martin Stokes (1994) speaks of the "musical construction of place" and Erlmann (1998) argues even for the existence of a so-called "practiced place", defined more by musical practices and networks of interactions than by its physical traits. In this sense we argue that sounds must be considered a key element in the distinction between a topos (place) and space, between the physical space and the socially inhabited place. ${ }^{4}$ In fact, spatially- (and temporally-) bound sounds are demarcating and commenting on our environment. They - beside vision and smell - charge space with meanings and affectivity. But the spatial environment can also have a profound impact on the way that we use our visual and auditory senses. Gell (1995), among others, has argued in the case of the Umeda in Papua New Guinea for the existence of an intimate relationship between the cultural factors which shape the phonology of certain natural languages and the particularities of the landscape in which the speakers live. Feld (2005) has observed in a similar way among the Kaluli of Bosavi a particular sense of acute hearing for locational orientation, needed in a rain forest environment in which visual orientation is limited.

3 A famous example in this respect is the pastoral Ranz des Vaches tune mentioned by Jean-Jacques Rousseau (1768: 317) which among Swiss soldiers abroad evoked yearning for their "lost" home.

4 A similar distinction has been brought up earlier by de Certeau (1984: 115) who distinguishes between "spaces" (espaces, place in use by people) and "places" (lieux, structured and material locations). 
If we speak about the role of sounds as social markers of space we must speak about silences as well: in which sense does sound relate to sociality and silence to asocial behaviour? In which sense is sound perceived as a commodity and silence as a menacing factor? Seremetakis (1990) has argued when discussing the lamenting practice in the Southern Peloponnese that silence plays the role of an important counterweight to sound in its constitutive function for gender and power relationships. In her contribution for the present dossier, Francesca Sbardella shows that both silence and sound are fundamental categories of nuns' lives in a monastic Catholic context. As the alternation between silence and ritual speech is the principal rule of collective coexistence and a condition for keeping the efficacy of the spiritual relation with god, production of sound is banned both by written, official rules of daily life and by incorporated habitus. Such explicit and suggested rules determine bodily behaviour, architecture and interior design. In the case explored, the nuns' great effort to maintain their sound environment contrasts with the relative freedom of lay people and groups, and proves that soundscapes are embodied social productions depending on different collective contexts. Silence in this example does not mean emptiness nor is it "devoid of sense" - on the contrary, silence is meaningful here; it is a highly symbolic resource which may be understood also in a Foucauldian sense as exemplifying power hierarchies (Foucault 1975).

But places are not only natural physical environments to be "filled" with sound. There are also places which are designed exclusively for the purpose of sound through techniques of acoustic engineering. This is the case with concert halls, designed for their acoustic properties. Comparable "artificially" constructed sound laboratories are analyzed in this dossier both through the lenses of a sound artist and an anthropologist's. Corsin Vogel produces sonic installations in which sound is one of the dimensions of the working space. Investigating the relationship between the sounds performed during work and the mental images they carry, Vogel tends to provoke individuals' imagination of space. Taken as immersive details of human life, the manipulated sounds contribute to construct a sound space in continuity with the physical space and the visitors' own expectations and imagination. The methodological principle of this sound artist is that sound is always a condition for the perception of space: on the one hand he makes the social dimension of the sonic environment visible in his work, on the other hand he makes us rethink our own relation with space as sonically determined. The contribution of Josée Laplace shows this entanglement between the function and the symbolics of a place on a very detailed and refined scale, taking the example of Catholic churches in Montreal to which people attribute particular sensitive qualities. She presents churches as particularly symbolically-charged places referring to the cultural background of the Quebeckers (secularization of the society and uncertainty 
of the future of these places). In her interpretation, consistent popular beliefs about churches as "exclusive spaces" do not correlate with ideas about a particular sound environment characterized by spirituality, slowness and gravity. Although "architectural discourse is largely silent on the impact of senses other than the visual" (Ripley 2007b: 98), anthropologists have showed a vital interest in the interaction between profane and sacred sound spaces and in the effects this has on the public and symbolic encodings of sound and architecture (Smith 2001; Paermentier 2008).

If we want to "read" spaces through listening to them, if we want to experience space sonically, we have to focus on the moment of performance. This is where social interaction, the interconnection between space, sound and memories becomes evident. Such performances may reveal also the identity-generating potential of place. Bandt, Duffy and MacKinnon (2007: 1) call the sonic characteristics through which we may reconstruct places "aural signatures". Listening to such "aural signatures" always has its moral and ethical implications, as the relationship between place and sound can be of a highly ideological nature which may lead up to the point in which sound becomes a factor in the dynamics of racial imagination (Radano and Bohlman 2000). The ways in which sounds become integrated or dominate over places correspond to socio-political power-relationships. This becomes evident if we consider, for example, the purified soundscapes or silences in borderlands, spaces of intense cultural contestation. But also in urban settings acoustic politics of space have been increasingly implemented. In such surroundings, "polluting" or "hybrid" sounds, contesting a fictive homogenous "national soundscape", are excluded. At the same time, sounds may play a subversive role in relation to the politics of sonic purification. Sounds may contest the space in which they occur. They may contest ideas of an "ethnic homogenous music practice", ideas of belonging, or they may contest the borders between tradition and modernity, between "Us" and the "Other". Sounds, in this sense, already participate in making more flexible our notions of locality, authenticity, belonging, identity and nationality.

They may also play a role as markers commenting on the marginality or strategic importance of space and place. The notion of "acoustic territories" (Labelle 2010) in urban surroundings refers to this increasing social stratification and hegemonization of sounds, pointing to a topography of auditory life as seen through the spatial and social structure of the city.

\section{SONIC DYNAMICS OF CONNECTED PLACES}

Increased human mobility has led to a situation where sounds also continuously change and interchange their places. Sounds increasingly detach from their place of production. Moreover, our contemporary world of mobility has 
proven that sound-space relations are and always have been cultural ones. Sound-space relations have been continuously reconfigured throughout history as they are socially conditioned.

The essentialist idea of sounds as being "naturally" tied to certain places and contexts has to be revised, as many sounds have found a new home in new contexts. This de-spatialization of sounds has become increasingly accelerated by media. It has resulted in what Slobin (1993) calls "transregional musics" - sounds with different local references. In a wider sense, sound, particularly world music, has become part of a global flow: “... world music looks like a fluid, interlocking set of style, repertoires, and practices that can expand or contract across wide or narrow stretches of the landscape. It no longer appears to be a catalogue of bounded entities of single, solid historical and geographical origins..." (Slobin 1993: 20).

This transregional aspect of contemporary musical practice can be exemplified by the success of the Mystères des voix bulgares or of the Corsican multipart group I Muvrini. In both cases, locally codified sounds became accessible and appreciated by a wider transregional audience through effective marketing strategies, which aimed at the "local branding" of sounds. Such phenomena must be considered in the context of a wider set of cultural politics and heritage politics, which provide regional and local goods with an aura of purity and authenticity. This often goes hand in hand with politically relevant processes of homogenisation and purification of entire musical landscapes. ${ }^{5}$

Sounds in the contemporary globalized world have not only switched between different local references, they have even opened up new dimensions beyond the physical reality: they have assumed an essential role in the imagination of places (Jankowski and Ingold 2012), and in the creation of visionscapes and mindscapes. This becomes particularly evident if we consider the crucial role sounds play as identifiers of belonging and homeliness in processes of de-territorialization, uprooting and displacement. As Levi and Scheding (2010) have convincingly shown, music plays a role before, during and after the event of displacement, acting as a reference for the longing for home, functioning as a retrospective "memorial soundscape". Indeed, in an increasingly mobile contemporary world sounds also are continuously on the move. In its sonic form, places, homes and origins travel with the people in their hand luggage, transcending movement. The sonic memory of an imagined and often fictive home remains present in its medialized form, even in the remotest corner of the Diaspora. De-territorialization forms the fertile ground for musical creativity and for a growing diasporic music industry, which strategically uses spatial and social nostalgia encoded in sound. They make a commercial

5 See similar comments in Kirshenblatt-Gimblett (1995: 373-375) about the homogenisation of heritage. 
use of the fact that music evokes a distant home for the migrant more effectively than everything else (e.g. Pistrick 2009; Isnart 2013).

This includes the possibility that sounds may refer also to a virtual, imagined space. One characteristic example are the so-called "Balkan Beats" which refer to a fictive (geographically imprecise), apolitical territory where excessive emotionality and musical virtuosity meet.

As Stoichiţă (2010) has argued, amplification has played another important role in opening new grounds for sonic experience beyond the established relation of sound and space. Unamplified sounds before were attributable to a certain physical and social space: they were intended to fill a certain space outside (like the wedding music of the Albanian-Macedonian zurna-daulle Ensemble) or the interior of a domestic space (like in the case of Bulgarian sedjanka songs). The amplified sounds of contemporary popular music practice go beyond this dichotomised relation of inside and outside spaces, and they extend far beyond the physical space. Electronic effects and amplification have lead to a disconnection between a physical but inaudible space and an invisible but sonically omnipresent space. The overall experience of such a sonic event is one of an amplified delocalized fugitive but omnipresent sound, exemplifying sonic power (Stoichiţă 2010: 9). In his article, Stoichiţă deals with amplification practices in depth, presenting the very technical aspect of the sonic production of reverb in Romanian performances of manele. He links the musicians' and listeners' representations of such sounds to the frameworks of Foucault and Gell. Arguing that manele performances using reverb lead to the epiphany of a temporary heterotopia characterised by a sonic, musical and poetic exotism, or "enchanted place", Stoichiţă shows the entanglements between the place of the performance and the place evoked by the performance. As many other artistic practices dealing with space and using a kind of splitting effect, the result is a superposition of the real place of performance and a virtual place.

The interaction between sound and place today is mediated in complex and often conflicting ways. Although the processes of a de-territorialization, transregionalization, and hybridization of sounds are found all over the contemporary world, at the same time tendencies to "spatialize" and "localize" sounds co-exist. They must be understood in a wider context of re-traditionalization and of heritage politics: in the logic of cultural policy makers, to "place" sounds means to provide them with an "authentic aura". The spatial settings, which could provide such an imagined "authenticity" for sounds, are rural folkloric festivals, historical monuments or revitalized religious feasts. The resulting dynamics of political ideologies, the interests of supra-national actors (such as UNESCO), or local movements of re-traditionalization act as agencies of power, knowledge and desire. They have reformulated the relation between sound and place profoundly. 
Nevertheless, even today there are musics which are primarily locally meaningful, created with local knowledges and sensibilities, telling particular narratives about the local, created for local audiences (Bennett, Whiteley and Hawkins 2005). The nation as a spatial point of reference for sonic practice is recently being reconsidered as a mediator between the larger global and the smaller local (Biddle and Knights 2007). Such musics play an important role in the way people define their relationships with local, everyday surroundings, at different scales, even in a globalized world. Local musics are understood by different cultural groups as being anchored in their sense of community, belonging, referring to a commonly shared past. In this dossier, Katell Morand gives us such an example in her sensitive and intimate ethnomusicological case study about an Ethiopian group of herdkeepers. Music playing, as it is the case in many pastoral cultures, can be seen as a specific and respected capacity of the herders, relating themselves to the herd during long periods of loneliness while on the pastures. In the author's view, the herders became, while working, not only masters in their own local musical practice, but also masters of the sonic images of their lands, and masters over the shared memories of collective village life. They build their spatial knowledge essentially on sonic perceptions of their environment, dealing with loneliness, wild animals and brigands in the liminal parts of the forest. But they also populate, occupy their environment with their own musical creations. Morand argues that the relation herdkeepers establish with their surrounding environment is essentially a sonic one. The herdkeepers live between two distinctly codified spatial entities: the cultivated social place of the village and the "asocial" wilderness. They try to exert control over this in-between space through sonic techniques which make them both connoisseurs and performers of highly localised and distinct soundscapes.

Considering the case study of Morand in this volume in relation to other contributions, such as those of Sbardella and Stoichiţă, we are challenged by a variety of questions: is the creation of soundscapes a conscious performative act which is largely conditioned by a particular socio-economic situation or is it a pre-conditioned cultural pattern, intrinsically linked to what we might call a cultural background, or a habitus? In which sense do soundscapes relate to the notion of the "local" or the "glocal"? What factors determine the (re)recognisability of soundscapes?

The contemporary relation of sound and space is a flexible and continuously changing one as is its future. As Labelle (2010) has pointed out, the temporal and evanescent nature of sounds imparts great flexibility and uncertainty to the stability of space (Labelle 2010: xxi). Whether the local meanings of sounds will regain their importance or whether the processes of de-territorialization and hybridization will lead to the disappearance of the local significance of sounds and see the creation of new spatial references is still uncertain. 


\section{REFERENCES}

ÁRNASON, Arnar, Nicolas ElLISON, Jo VERGUNST, and Andrew WHITEHOUSE (eds.), 2012, Landscapes beyond Land: Routes, Aesthetics, Narratives. New York, Berghahn Books. BANDT, Ros, Michelle DUFFY, and Dolly MacKINNON (eds.), 2007, Hearing Places: Sound, Place, Time, and Culture. Newcastle, Cambridge Scholars Publishers.

BENNETT, Andy, Sheila WHITELEY, and Stan HAWKINS (eds.), 2005, Music, Space and Place: Popular Music and Cultural Identity. Lanham, Ashgate.

BIDDLE, Ian, and Vanessa KNIGHTS (eds.), 2007, Music, National Identity and the Politics of Location. Between the Global and the Local. Lanham, Ashgate.

CARNEY, George O., 1998, "Music geography", Journal of Cultural Geography, 18 (1): 1-10. CLER, Jerome, 1999, "Paysages musicaux: une approche musicologique”, Ktema, 24: 259-267. DAVIDSON, Joyce, and Christine MILLIGAN (eds.), 2004, "Embodying emotion, sensing space: introducing emotional geographies", special issue, Social and Cultural Geography, 5 (4): 523-532.

DAVIDSON, Joyce, Liz BONDI, and Mick SMITH (eds.), 2005, Emotional Geographies. Farnham, Ashgate.

DE CERTEAU, Michel, 1984, The Practice of Everyday Life. Berkeley, CA, University of California Press.

ERLMANN, Veit, 1998, "How beautiful is small? Music, globalization and the aesthetics of the local”, Yearbook for Traditional Music, 30: 12-21.

ERLMANN, Veit, 2004, Hearing Cultures: Essays on Sound, Listening and Modernity. Oxford, Berg.

FELD, Steven, 1982, Sound and Sentiment: Bird, Weeping, Poetics and Song in Kaluli Expression. Philadelphia, University of Pennsylvania Press.

FELD, Steven, 2005, "Places sensed, senses placed: toward a sensuous epistemology of environments", in David Howes (ed.), Empire of the Senses: The Sensual Culture Reader. Oxford and New York, Berg, 179-192.

FOUCAUlT, Michel, 1975, Discipline and Punish: The Birth of the Prison. New York, Random House.

GELL, Alfred, 1995, "The language of the forest: landscape and phonological iconism in Umeda”, in Eric Hirsch and Michael O'Hanlon (eds.), The Anthropology of Landscape: Perspectives on Place and Space. Oxford, Clarendon Press, 232-254.

HALBWACHS, Maurice, 1992 [1941], "The legendary topography of the gospels in the Holy Land: conclusions", in Maurice Halbwachs, On Collective Memory. Chicago and London, The University of Chicago Press, 193-235.

HOWES, David (ed.), 1991, The Varieties of Sensory Experience: A Sourcebook in the Anthropology of the Senses. Toronto, University of Toronto Press.

INGOLD, Tim, 2007, "Against soundscape", in E. Carlyle (ed.), Autumn Leaves: Sound and the Environment in Artistic Practice. Paris, Double Entendre, 10-13.

INGOLD, Tim, 201 1, Being Alive: Essays on Movement, Knowledge and Description. London, Routledge.

ISNART, Cyril, 2013, "Espace du passé: Evocations mémorielles et hétérotopie a Viévola (Tende)", Ethnologie Française, 43: 77-84.

JANKOWSKI, Monica, and Tim INGOLD (eds.), 2012, Imagining Landscapes: Past, Present and Future. Lanham, Ashgate. 
KIRSHENBLATT-GIMBLETT, Barbara, 1995, “Theorizing heritage”, Ethnomusicology, 39 (3): 367-380.

LABELLE, Brandon, 2010, Acoustic Territories: Sound Culture and Everyday Life. New York and London, Continuum Books.

LEFEBVRE, Henri, 1974. La production de l'espace. Paris, Anthropos.

LEVI, Erik, and Florian SCHEDING (eds.), 2010, Music and Displacement: Diasporas, Mobilities, and Dislocations in Europe and beyond. Lanham, Scarecrow Press.

LEYSHON, Andrew, David MATleSS, and George REVILl (eds.), 1998, The Place of Music. New York, The Guildford Press.

MASSEY, Doreen, 1992, "A place called home”, New Formations, 17: 3-15.

MATLESS, David, 2005, "Sonic geography in a nature region", Social and Cultural Geography, 6 (5): 745-766.

PAERMENTIER, Els de, 2008, "Experiencing space through women's convent rules: the rich clares in medieval Ghent (thirteenth to fourtheenth centuries)", Medieval Feminist Forum, 44 (1): 53-68.

PISTRICK, Eckehard, 2009, "Singing of pain and memory: emotionalizing mythistory of migration in Epirus", Zeitschrift für Balkanologie, 45 (1): 66-76.

RADANO, Ronald M., and Philip V. BOHLMAN (eds.), 2000, Music and Racial Imagination. Chicago, The University of Chicago Press.

RIPLEY, Colin, 2007a, "Introduction: in the place of sound", in Colin Ripley, Marco Polo and Arthur Wrigglesworth (eds.), In the Place of Sound: Architecture, Music, Acoustics. Newcastle, Cambridge Scholars Publishing, 1-11.

RIPLEY, Colin, 2007b, "Hearing places: sound in architectural thought and practice", in Ros Bandt, Michelle Duffy and Dolly MacKinddon (eds.), Hearing Places: Sound, Place, Time, and Culture. Newcastle, Cambridge Scholars Publishers, 95-107.

ROUSSEAU, Jean-Jacques, 1768, Dictionnaire de musique. Paris, Veuve Duchesne.

SEAMON, David, and Robert David MUGERAUER (eds.), 1985, Dwelling, Place, Environment: Toward a Phenomenology of Person and World. Dordrecht, M. Nijhoff.

SEREMETAKIS, Nadia C., 1990, "The ethics of antiphony: the social construction of pain, gender, and power in the Southern Peloponnese", Ethos, 18 (4): 481-512.

SLOBIN, Mark, 1993, Subcultural Sounds: Micromusics of the West. Hanover and London, Wesleyan University Press.

SMITH, Julie Ann, 2001, Ordering Women's Lives: Penitentials and Nunnery Rules in the Early Medieval West. Aldershot, Ashgate.

STOICHIŢA, Victor, 2010, "The squire in the helicopter: on parody in Romanian popular music", to be published in Yearbook of the New Europe College 2009-2010, available at <http://halshs.archives-ouvertes.fr/docs/00/69/01/58/PDF/Stoichita_Squire-in-helicopter.pdf $>$ (accessed on 17/03/2013).

STOKES, Martin (ed.), 1994, Ethnicity, Identity and Music: The Musical Construction of Place. Oxford, Berg.

STOLLER, Paul, 1989, The Taste of Ethnographic Things: The Senses in Anthropology. Philadelphia, University of Pennsylvania Press.

TUAN, Yi-Fu, 1975, "Place: an experiental perspective", Geographical Review, 65 (2): 151-165. 